\section{THE LYMPHATIC SYSTEM OF THE ANTERIOR LIMB IN DASYPUS NOVEMCINCTUS NOVEMCINCTUS LINNE, 1758 (MAMMALLA: EDENTATA)}

LEONOR GABRIELA GAUNA ANASCO

Facultad de Ciencias Veterinarias Repúbl ica Argentina

IRENE VON LAWZEWITSCH Professor Titular Facultad de Ciencias Veterinarias República Argent ina

GAUNA ANASCO, L.G. \& LAWZEWITSCH, I. The Lymphatic system of the anterior limb in Dasypus novemcincrus novemcincaus Linne, 1758 (Mamalia: Edentata). Braz J. vet. Res. anim. Sci., São Paulo, 27(2):145-151, 1990

SUMMARY: The aim of this work is to realize a revision of the anterior limb lymphatic draining of the Dasypus novemcinctus novemcinctus. 15 armadillos clinically healthy, male and female were utilized; they had been captured in the Argentine Northeast and were injected by the Gerota's Paste modified method. The injection was realized at the fourth toe level on the medial side as well as on the lateral one; on the interphalangeal area, and on the left one over the mammary gland of both sides. The classical dissections were carried out with a surgery microscope, of Varimex type. The microphotographs were realized with a Zeiss microscope. The exhaustive analys is of the anterior limb area showed the following conclusions: the lymphatic circulation was observed from the distal extremity of the injected area to the axillar lymphocenter from where emitted 2 or 3 efferent lymphatic vessels; they were directed to the superficial inguinofemoral lymphonodule. The limphonodule situated by the scapula caudal border received one efferent lymphatic vessel which came from the superficial cervical Iymphonodule and another efferent lymphatic vessel which led to the axillar lymphocenter.

UNTERMS: Armadillo, Dasypus novemcincus novemcincaus; Lymphatic system; Marmary gland

\section{INTRODUCTION}

Since the armadillo Desypus novemcinctus novemcincrus has been utilized as a laboratory animal in the study of metabolic diseases, e.g. the experimental leprosy, it is important to obtain exact data about the Morphology, Physiology and Pathology of these animals. Consequently it is necessary to go deep into more studies about the lymphatic system which would afford the observation of some aspects scanty known, particulary in the transmission of the leprae bacillus by experi. mental inoculation. Moreover, these specimens play a basic role in the epidemiologic chain of the infections and transmissible diseases, without mentioning the important role that they accomplish in the compared Pathology and Public Health. Besides, they are important in the management of a breeding stock.

The bibliography shows that these studies are incomplete, particularly in Veterinary Medicine, and also with reference of the lymphatic system to the Dasypodidade family described by AZZALI \& DIDIO 1 (1966).

These authors realized a general revision on this system of the armadillo (GAUNA ANASCO \& MOLINA 4 , 1985). For the comparison of the mentioned area in pathological cases, it is first necessary to complete and extend the topographic distribution and localization of the lymphatic drainage in the anterior limb of the Dasypus in normal conditions.

It must be pointed out that it has not been registered with exception of the above mentioned author any other case of morphological antecedents about the lymphatic system in the nine bands armadillo. With respect to the histological part of the lymph nodes there exists only the Caparo's, histological collection of 7-bands armadillo ${ }^{2}$.

\section{MATERLAL AND METHOD}

The material coming from the Argent ine Northeast consisted of 15 adult male and female armadillos, in good semiologic conditions. The specimen anesthetized with penthotal sodium was placed on a stretcher in supine position, and its limbs were fastened with gauze strips. It was applied the Gerota's technique modified by CAPLAN ${ }^{3}$ (1977).

The I.D. injections were performed with a carpoole syringe and 23 to 30 gauge needles in the interdigital space of the fourth toe in the medial side as well as in the lateral one and on the left pectoral marmary gland. It was necessary to make smooth massages in the injection area to favor the dye circulation. Going on with the proceeding the material 
was placed in a recipient with $40 \%$ formol for $7-8$ days and after skinning it was placed in one of 100 volumes hydrogen peroxide for 5-7 days. For the dissection performing, delicate instruments were utilized: thin tweezers as those used in ocular microsurgery, a 200 watts lamp with a magnifying glass for a focal distance of $20 \mathrm{~cm}$, or the surgery microscope, Varimex type.

The size of the several Iymphocenters (including the (ymphonodules was taken with a $0,005 \mathrm{~mm}$. caliber).

The histological study of the different Iymphatic nodules was performed by conventional techniques and the photomicrographies were obtained on a microscope zeiss.

\section{RESULTS AND DISCUSSION}

After an exhaustive analysis of the injected areas we obtained the following data which concern to the axillar Iymphocenter (Lymphocentrum axillare). This area presented 1 or 2 lymphatic nodules with an arithmetical average of $2,2 \mathrm{~cm}$ length and $0,7 \mathrm{~cm}$ width; the elongated, rounded and flat shapes were predominant. Considering the location of the said lymphocenter, 10 cases evidenced their situation in the axillar cavity on the thoracic wall at the second and third band level being wrapped in plenty of adipose tissue. The Iymphatic nodules presented 1 or 2 tymphatic vessels which allowed the internodular connection. From the remaining 5 specimens the lymphatic nodules were seen lying in an oblique position at the fifth, sixth and seventh ribs height over the local muscular mass. In all the observed cases this lymphocenter lymphonodules emitted 1 or 2 efferent lymphatic vessels which projected to the prefemoral lymphocenter sliding superficially over the thoraco-abdominal muscular area (GAUNA ANASCO \& MOLINA 4 , 1985) (Fig. 1).

Along with the lymphonodule craneal part, the fusion of 2 or 3 efferent collecting lymphatic vessels was also observed and after a short course they formed an unique lymphatic vessel which led to the right Iymphatic conduct (Ductus lymphaticus dexer) on the same side, as it is stated by AZZALI \& DIDIO ${ }^{1}$ (1966).

The Dasypus novemcincus novemcincus specimen is very difficult to be dissected owing to its strong constitution; by that reason the animals shells have to be taken away before their placing in formol; this is necessary to avoid the muscular masses decomposition. After the shells withdrawing we have found $a$ lymphonodule lying by the caudal border of the scapula; it was near the dorsal border over the thoracic ventral muscle and was covered by the lattisimus dorsi muscle (Fig.2). On the left side 15 lympnonodules were observed, their average width was from $0,7 \mathrm{~cm}$ to $0,5 \mathrm{~cm}$. On the right side 14 lymphatic nodules were dissected with an average width from $1 \mathrm{~cm}$ to $0,8 \mathrm{~cm}$; they were mostly round shaped and elongated, they were oviform in 5 cases only. This lymphonodule emitted a lymphatic vessel which drained to the superficial cervical lymphatic nodule (lymphonodi superficial cervicals). In 10 cases it was proved that it gave $r$ ise to another efferent lymphatic vessel which interconnected the Iymphonodules of the axillar tymphocenter.

AZZALI \& DIDIO 1 (1966) studied the lymphatic system of 40 armadillos (Species Dasypus novemcincus novemcinctus); they utilized a Prussian blue suspension, neoprene latex and lymphographic studies which pointed out evidently the submandibular (ymphocenter chain (lymphocentrum mandibulare), the auricleparotoid lymphocenter (Iymphocentrum parotideum) and the superficial cervical, but these authors did not mention the presence of the Iymphatic nodule lying by the scapula caudal border, which we dissected in our animals.

from the studied lymphonodules of the dorsal area we may infer that the cortical zone consists of lymphoid tissue which spreads under the organ capsule in such a way that mostly of the filtration is performed by the medullary area. In the same it can be detected a large net of lymphatic sinus whose lumen is occupied by the reticular tissue.

In the latter, cells with anastomosed cytoplasmatic elongations are seen very neatly, as well as others round shaped, with a central nucleus and without cytoplasmatic elongations. This display is characteristic of the Dasypodidae family and we agree with statements (CAPARO ${ }^{2}, 1979$ ) (Fig. 3 and 4 ).

The elements utilized for the development of this work have proved that the needles used are made of a very weak material to carry out an injection which must be realized in the narrow space existing between the toes plates, thus avoiding a negative application of the dye. It must be kept in mind also, the dense structure of these armadillos' skin; consequently it is suggested that the inoculation should be done with a high pressure.

\section{CONCLUSION}

In all the cases observed have been checked 1, 2 and 3 lymphatic afferent vessels which extend from the hand dorsal region up to the axillar Iymphocenter. Considering the efferent lymphatic vessels their number ranges from 2 to 5 and they conduce to the superficial inguino-femoral lymphonodule.

Brazz J. vel. Res. anim. Sci. , São Paulo, 27(2):145-151, 1990. 
It is stated that the lymphonodule to be found lying by the scapula caudal border is considered as one lymphatic nodule completing the anterior limb lymphatic net, more not only by its topographical situation but also by the lymphatic distribution seen in the correlated limb and the neighboring lymphocenters.

After one injection realized at the level of the left pectoral mamary gland, lymphatic vessels which spread out to the axillar lymphocenter are observed but is not seen any emission of branches to the other anterior limb.

From the chosen injection area (fourth toe and interdigital space) it is not observed any (ymphatic communication with the opposed anterior limb.

GAUNA ANASCO, L.G. \& LAWZEWITSCH, I. O sistema linfático do membro torácico em tatu (Dasypus novemcincrus novemcinctus). Braz J. vel Res. anim. Sci, São Paulo, $27(2): 145-151,1990$.

RESUMO: Revisão a respeito da drenagem linfática do membro anterior em Dasypus novemcincus novemcinctus. For am utilizados 15 tatus, clinicamente sãos, de ambos os sexos, capturados no Nordeste Argentino $e$ injetados segundo o método da "Pasta de Gerota Modificada". A punção foí realizada no quarto dedo tanto medial quanto lateralmente, na zona interfalangiana e de anbos os lados da glândula manária peitoral esquerda. As dissecaçōes clássicas foran realizadas utilizandose microscópio de cirurgia tipo varimex. As fotomicrografias foram tomadas com auxilio de microscópio tipo zeiss. A análise exaustiva da região do membro torácico levou-nos às seguintes conclusōes: - percurso linfático se efetuava desde a extremidade distal da regiāo injetada até o linfonodo axilar, deste partindo 2 a 3 vasos linfáticos eferentes que se projetavam no linfonodo inguinofemoral superficial. 0 linfonodo situado junto à borda caudal da escápula (descrito pela primeira vez) recebia vaso linfático eferente do linfonodo cervical superficial e outro vaso linfático eferente que se projetava en direção ao linfonodo axilar.

UNITERMOS: Tatu, Dasypus novemcinctus novemcinctus; Sistema L infático, tatu; Manas, tatu
REFERENCES

01-AZZALI, G. \& DIDIO, J.A.L. The lymphatic system of Dasypus novemcinctus novemcinctus and Dasypus sexcintus. J. Morph, 117:42-72, 1966.

02-CAPARO, A.C. Atlas de histologia del armadillo de 7-bandas (Dasypus hubridus). Buenos Aires, OMS/OPS, 1979.

03-CAPLAN, I. Le système lymphatique du pouce. Rev. Méd., Paris, 32:1-65, 1977.

04-GAUNA ANASCO, L.G. \& MOLINA, F. El sistema linfático del miembro posterior de Dasypus novemcincaus novemcuncaus. Linné, 1758 (Mammalia: Edentata). História Naturah, S(33):305-308, 1985.

05-GEROTA, D. Zur systéme lymphgefass injection. E ine neue injectionsmasse für lymphgefasse, polychrome injection. Anat Anz, 12:216-224, 1896.

Recebido para publicaçào em 13/06/89

Aprovado para publicaçāo em 14/11/89 


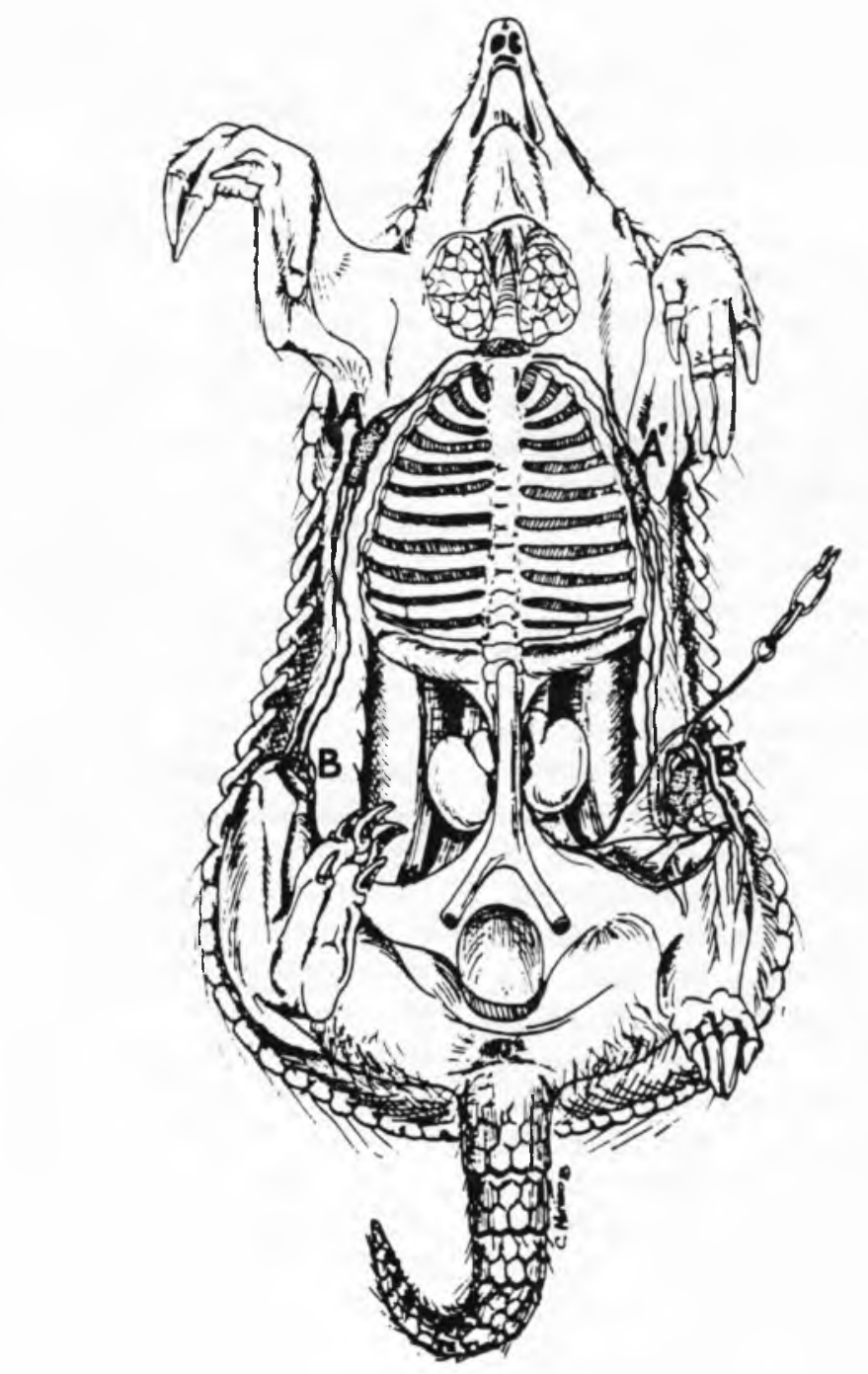

FIGURE 1 - The axillary lymphocenter ( $\left.A-A^{\prime}\right)$, originating 2 or 3 Iymphatic vessels which project to the prefemoral lymphocenter ( B-B'). 
The lymphatic system of the anterior limb in Dasypus novemcinctus novemcinctus. Linne, $1758 \ldots$

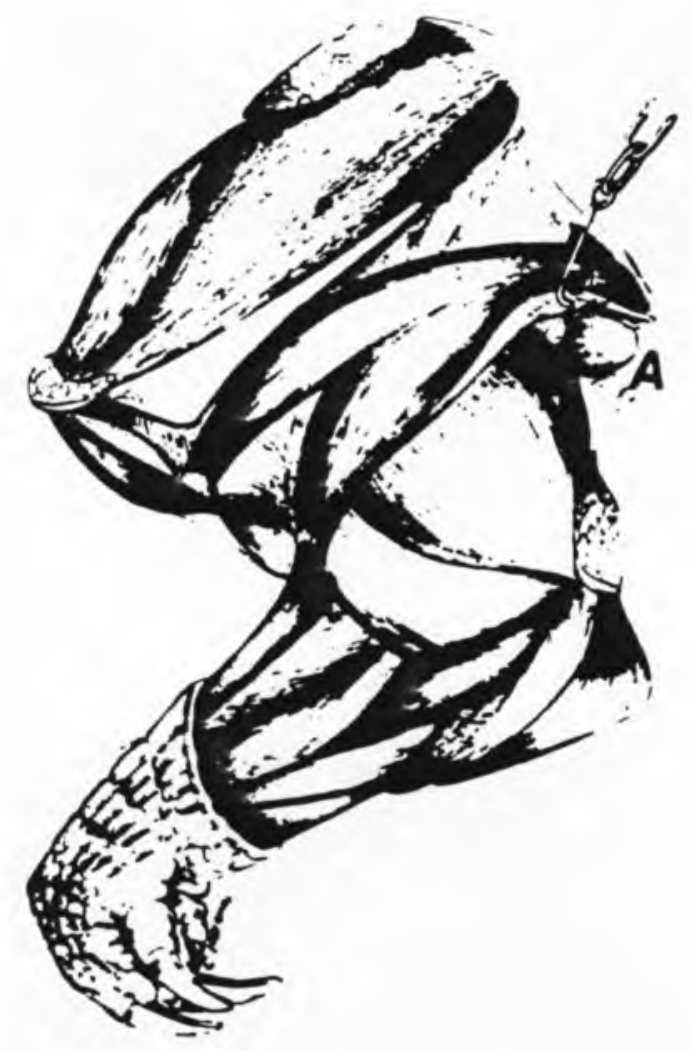

FIGURE 2- A: Lymphonodule situated beside the caudal border of the scapula, near the dorsal edge, placed on the anterior part of the shell. 


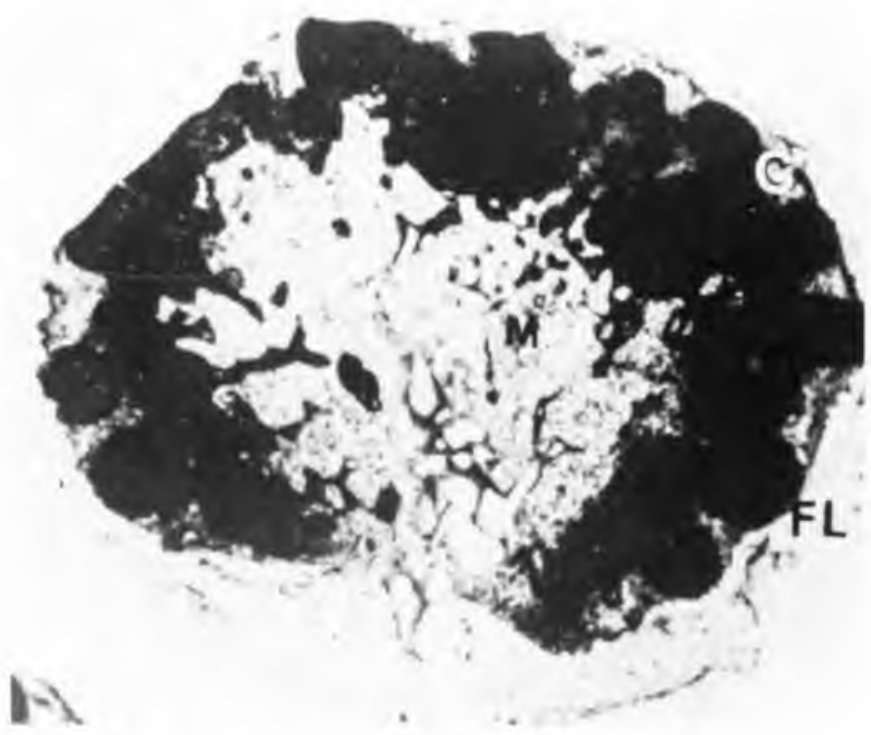

FIG. 3 - Lymphatic nodule section related to Figure 2. C: cortical area where plenty of lymphoid follicles project (FL) and the med ullary area (M) without lymphoid tissues; it is formed by lymphatic sinuses only.

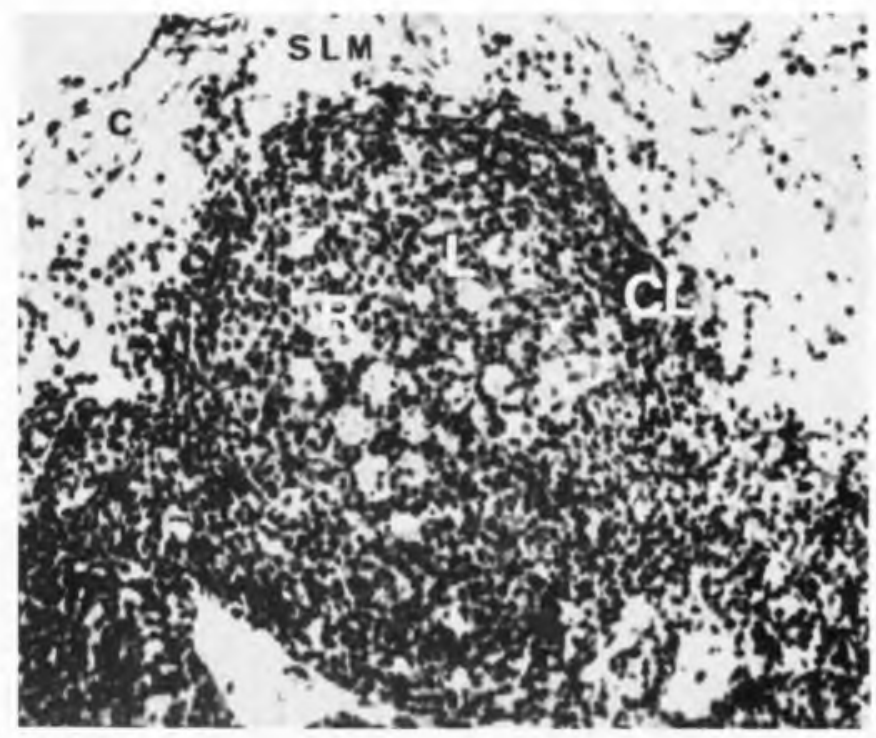

FIG. 4 - The follicle central part is observed presenting cells of the lymphoblast type (L), cells of the reticular type $(R)$; at the periphery it is seen the lymphocytic cells halo (CL). On the upper part, the marginal lymphatic sinus surrounding the follicle (SLM) and the capsule (C). 